\title{
Oligella ureolytica
}

National Cancer Institute

\section{Source}

National Cancer Institute. Oligella ureolytica. NCI Thesaurus. Code C86625.

A species of aerobic, Gram-negative, coccobacilli shaped bacteria assigned to the phylum Proteobacteria. This species is motile using peritrichous flagella (most strains), nonspore forming, noncapsulated, moderately fastidious, oxidase, catalase and urease positive, indole negative, reduces nitrate and nitrite, nonhemolytic, not susceptible to penicillin, and does not produce hydrogen sulfide, pigment or odors, hydrolyze gelatin and ferment or oxidize carbohydrates. O. ureolytica is commensal to the genitourinary, but can become pathogenic during long term catheterization or in immunocompromised individuals. 